\title{
Neolithic farmers or Neolithic foragers? Organic residue analysis of early pottery from Rakushechny Yar on the Lower Don (Russia)
}

\author{
Manon Bondetti ${ }^{1,2}$ (D) $\cdot$ Lara González Carretero $^{3} \cdot$ Ekaterina Dolbunova $^{3,4} \cdot$ Krista McGrath $^{5} \cdot$ Sam Presslee $^{1}$. \\ Alexandre Lucquin ${ }^{1} \cdot$ Viktor Tsybriy $^{6} \cdot$ Andrey Mazurkevich $^{4} \cdot$ Andrey Tsybriy $^{6} \cdot$ Peter Jordan $^{7} \cdot$ Carl Heron $^{3}$. \\ John Meadows ${ }^{8}$. Oliver E. Craig ${ }^{1}$
}

Received: 21 December 2020 / Accepted: 2 July 2021 / Published online: 26 July 2021

(c) Crown 2021

\begin{abstract}
The emergence of pottery in Europe is associated with two distinct traditions: hunter-gatherers in the east of the continent during the early 6th millennium BC and early agricultural communities in the south-west in the late 7th millennium BC. Here we investigate the function of pottery from the site of Rakushechny Yar, located at the Southern fringe of Eastern Europe, in this putative contact zone between these two economic 'worlds'. To investigate, organic residue analysis was conducted on 120 samples from the Early Neolithic phase (ca. mid- $6^{\text {th }}$ millennium BC) along with microscopic and SEM analysis of associated foodcrusts. The results showed that the earliest phase of pottery use was predominantly used to process riverine resources. Many of the vessels have molecular and isotopic characteristics consistent with migratory fish, such as sturgeon, confirmed by the identification of sturgeon bony structures embedded in the charred surface deposits. There was no evidence of dairy products in any of the vessels, despite the fact these have been routinely identified in coeval sites to the south. Further analysis of some of the mammalian bones using ZooMS failed to demonstrate that domesticated animals were present in the Early Neolithic. Nevertheless, we argue that intensive exploitation of seasonally migratory fish, accompanied by large-scale pottery production, created storable surpluses that led to similar socio-economic outcomes as documented in early agricultural societies.
\end{abstract}

Keywords Pottery $\cdot$ Early Neolithic hunter-gatherer $\cdot$ Farmers $\cdot$ Lipid residue analysis $\cdot$ ZooMS $\cdot$ Scanning electron microscopy (SEM)

\section{Introduction}

The transition to the Neolithic marks a period of profound socio-economic change, often related to increased sedentism, intensification of subsistence practices with the rise

Manon Bondetti

manon.bondetti@york.ac.uk

1 BioArCh, University of York, Environment Building, Wentworth Way Heslington, York YO10 5DD, UK

2 Arctic Centre and Groningen Institute of Archaeology (GIA), University of Groningen, Aweg 30, 9718CW Groningen, The Netherlands

3 Department of Scientific Research, The British Museum, London WC1B 3DG, UK

4 Department of Archaeology of Eastern Europe and Siberia, The State Hermitage Museum, 34 Dvortsovaya Embankment, Saint Petersburg 190000, Russian Federation of new, more specialist strategies. Yet the economic transition that underpins this process has been interpreted differently. In the Western European archaeological tradition, 'Neolithisation' specifically refers to the economic transition from foraging to agriculture and the rearing of domesticated

5 ICTA, Universitate Autonoma de Barcelona, UAB 08193 Bellaterra (Cerdanyola), Building Z Campus, Barcelona, Spain

6 Don Archaeological Society, 95A M Gorkogo, Rostov-on-Don, Russian Federation

7 Department of Archaeology and Ancient History, Lund University, Lund, Sweden

8 Centre for Baltic and Scandinavian Archaeology (ZBSA), SchlossGottorf, Schleswig-Holstein State Museums Foundation, Schlossinsel 1, 24837 Schleswig, Germany 
livestock, and is often associated with the introduction of a package of innovations, including pottery (Dixon 1928; Childe 1951; Kuzmin 2013; Hommel 2014). To prehistorians working in northern Eurasia, however, the Neolithic denotes the emergence of pottery production invariably amongst hunter-gatherer communities (Zhukov 1929; Chard 1974; Barnes 1999; Gibbs and Jordan 2016). For the latter, the degree to which the inception of pottery transformed hunter-gatherer subsistence practices is debated (Jordan and Zvelebil 2009). This debate has recently been fuelled by chemical analysis of early hunter-gatherer ceramic vessels allowing determination of their use. Based on evidence from Northern Europe and East Asia, it appears that aquatic foods were preferentially cooked in hunter-gatherer vessels, perhaps marking intensification of fishing at this time, leading to surplus production and creating the conditions for increased sedentism and population growth (e.g. Craig et al. 2007, 2011, 2013; Bērziņš 2010; Lucquin et al. 2016b, 2018; Oras et al. 2017; Shoda et al. 2017; Gibbs et al. 2017; Bondetti et al. 2020b). However, other studies have shown more variable patterns of use which, arguably, reflect economic continuity from the preceding 'Mesolithic' period (Oras et al. 2017; Bondetti et al. 2020b), where it is argued that intensified fishing was already established (e.g. Bērziņš 2010) or came later.

In Europe, pottery was used by both hunter-gatherers in the north-east of the continent, during the early 6th millennium BC (Piezonka 2011; Kriiska et al. 2017) and by the first agricultural communities, such as those in the Balkans, at least by the end of the 7th millennium (Krauß et al. 2018; Fig. 1a). From the available dates and site locations, it is often assumed that these pottery traditions were associated with quite separate cultural trajectories with independent origins (Dolukhanov et al. 2009a, b; Davison et al. 2009; Fuller et al. 2015; Jordan et al. 2016). Eurasian hunter-gatherers and early farmers had different uses for pottery; aquatic products are largely absent from pottery produced by early farming communities, which are instead dominated by ruminant products including dairy products (Evershed et al. 2008b; Nieuwenhuyse et al. 2015; Debono Spiteri et al. 2016). These findings support the notion that ceramic using foragers and early farmers operated in two independent worlds (Gronenborn 2008).

Some of the earliest pottery vessels in Europe are found in the North Pontic-Caspian steppe during the early 6th millennium BC; a region lying between these worlds (Fig. 1a). Here, knowledge of ceramic production may have been acquired by hunter-gatherers from agriculturalists and pastoralists already established in Anatolia and the Caucasus (Fig. 1a) or brought directly by farmers who moved into this region and adjusted their practices by adopting a mixed foraging/farming economy. Alternatively, pottery production may have been introduced by other forager communities to the north and east or may even have been a quite separate local innovation. Unfortunately, dating the arrival of pottery throughout this region at the required precision to investigate these questions is currently hampered by the lack of detailed site-based chronological models. The problem is further exacerbated as individual dates of hunter-gatherer vessels are often made on adhering charred 'foodcrusts' which may be subject to significant freshwater or marine reservoir effects (Fischer and Heinemeier 2003; Philippsen 2013).

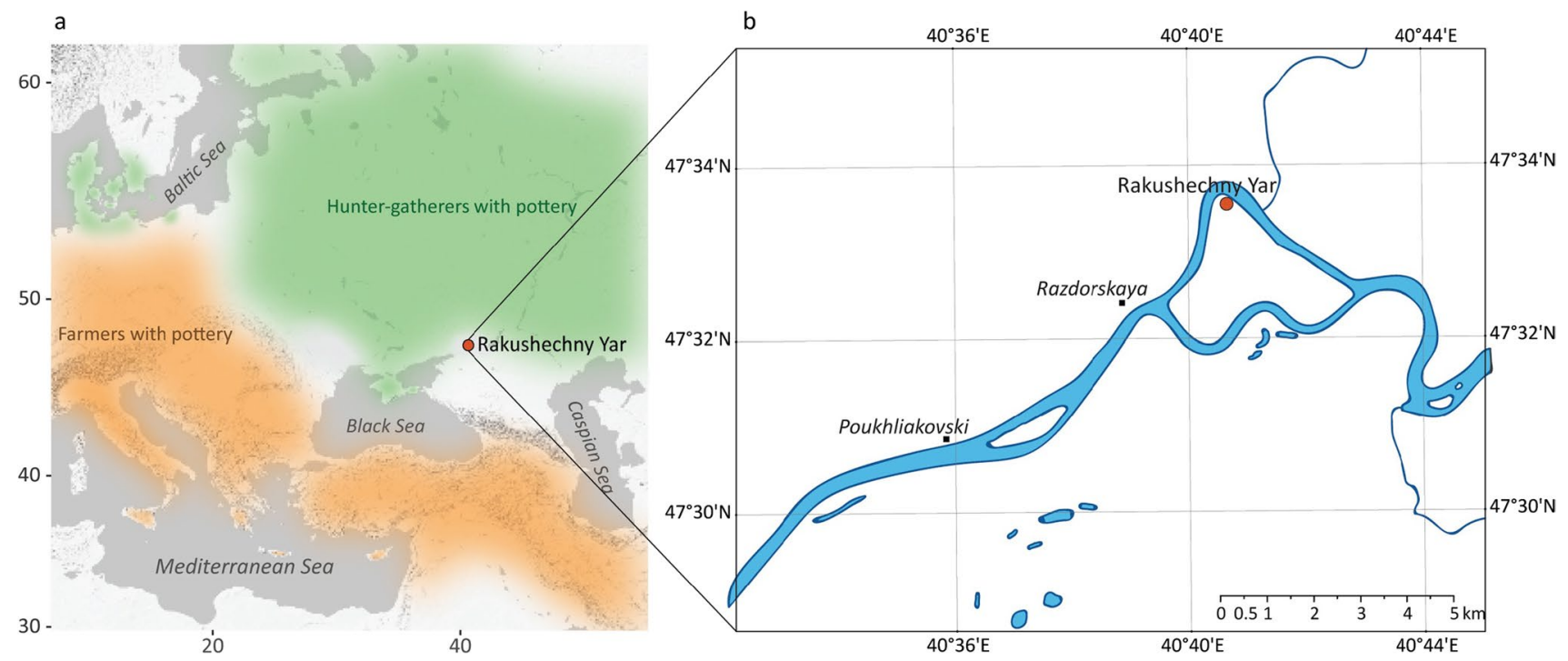

Fig. 1 A simplified map (a) showing the location of Rakushechny Yar at the southern fringe of Eastern Europe (Russia), lying between ceramic foragers and farmers at $c a$. $5000 \mathrm{cal}$ BC (b) showing the location of Rakushechny Yar on Porechny Island, in the lower Don River 
In order to examine the different aspects of pottery production in this region, here we present lipid residue analysis of vessels from one of the key sites, Rakushechny Yar, a hunter-gatherer site situated close to the putative forager/ farmer contact zone in the Pontic steppe (Fig. 1a) that dates from the mid/late 6th millennium BC (Supplementary Materials). Residue analysis provides direct evidence of vessel use, from which we can infer possible functions and hence the motivations for the adoption of this technology by hunter-gatherers at regional and sub-regionals scales, as well as contributing to the emerging picture of regional variability in early pottery use in North-Eastern Europe (Courel et al. 2020). We were also interested in whether domesticated animal products were present, particularly on ceramic from the earliest layers at the site. If so, this evidence would support the hypothesis that pottery in this region was acquired through interaction with farmers and more broadly that ideas, materials and people flowed across the 'boundary' between foragers and farmers (RowleyConwy et al. 2014).

In support of the latter hypothesis, analysis of material culture found at Rakushechny Yar and more broadly in the North Pontic region suggests that the region was embedded in a wide cultural network that possibly encompassed farming communities to the south (Gorelik et al 2016). Neolithic obsidian from Southern Ukraine was obtained from Armenia and Central Anatolia (Biagi et al. 2014) and the presence of wattle-and-daub architecture at Rakushechny Yar (layer 11) and a female figurine (layer 10) (Belanovskaya 1995; Tsybrij et al. 2017) are similar to the many found in Anatolia (Cauvin 2000; Budja 2005,
2009). Similarly, Early Neolithic pottery at Rakushechny Yar is noted to share some technological and morphological attributes with SW Asian pottery produced by farmers (Vandiver 1987; Le Mière and Picon 1998; Nishiaki and Le Mière 2005; Budja 2009; Mazurkevich and Dolbunova 2015). Whilst there are also some shared technological and morphological traits between the Rakushechny Yar pottery and hunter-gatherers pottery from the neighbouring Lower Volga region, both the ceramic manufacturing techniques and the high proportion of undecorated pottery appear to have been quite different (Mazurkevich et al. 2017; Mazurkevich and Dolbunova 2012, 2015). Thus, the origin of the pottery at Rakushechny Yar based on stylistic and technological aspects is still unclear.

Although the faunal remains at Rakushechny Yar show that the site is clearly associated with hunting and fishing, it has also been reported that domesticated animals (cattle, Bos taurus, sheep, Ovis aries, goat, Capra hircus, pig, Sus domesticus, Fig. 2) were present in the faunal assemblage (from layer 21; (Belanovskaya 1995; Tsybrij et al. 2017). The presence of wild cattle and wild boar in this region precludes the secure identification of domesticated forms of these species on morphological criteria. In contrast, wild sheep and goats are thought to have been absent (Bobrinskoy et al. 1944), so the presence of these taxa would provide clear evidence of domestication. A second aim therefore was to use molecular identification (ZooMS) and AMS dating of mammalian bone to confirm or refute the presence of domesticated sheep/goat during the early phases of the site.

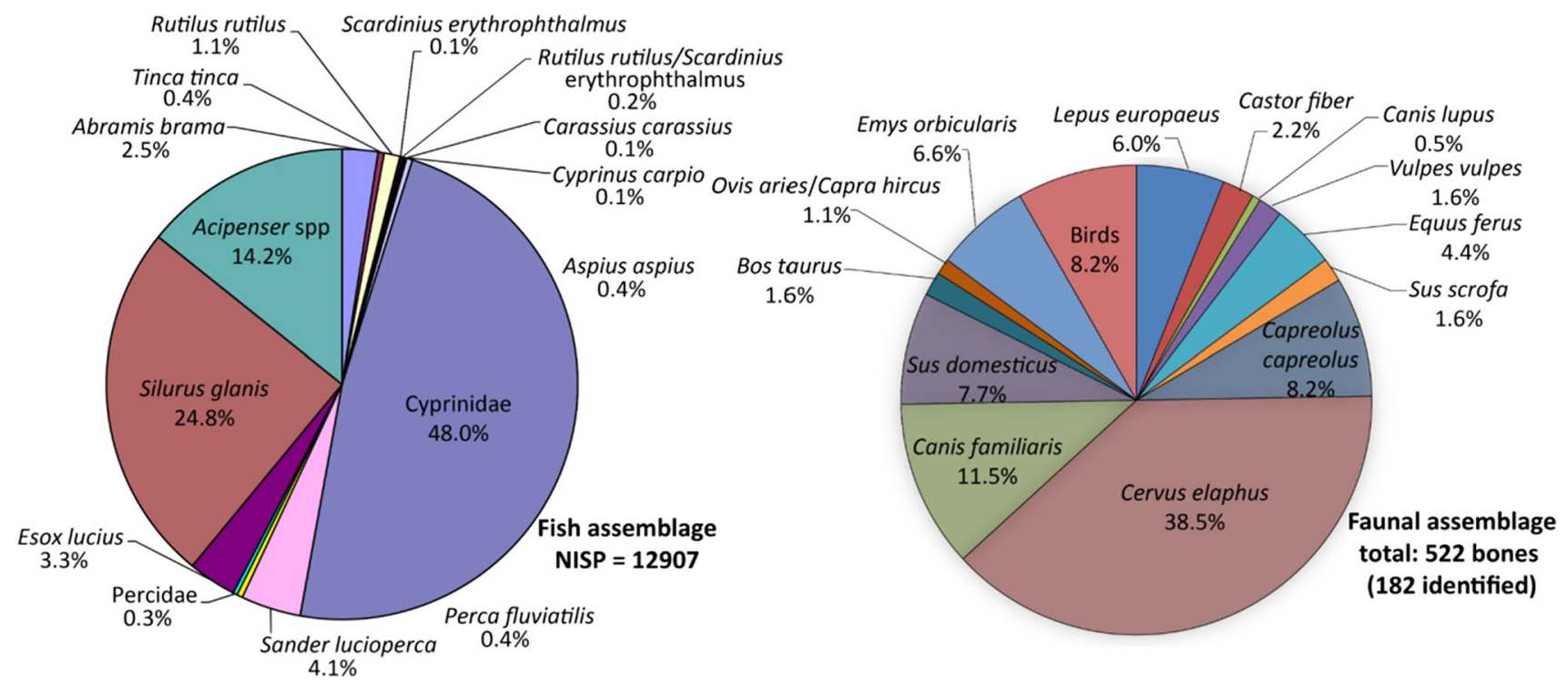

Fig. 2 Archaeozoological assemblage distribution of fish and terrestrial animals from the Early Neolithic phase of Rakushechny Yar (Sablin 2018) 


\section{Rakushechny Yar: site and context}

Rakushechny Yar is located on the northwest part of Porechny Island (Fig. 1b). The site was established on the shoreline of an ancient naturally dammed lake (Dolbunova et al. 2020b). The first stage of occupation at Rakushechny Yar by Early Neolithic communities was initially dated to the 7th millennium BC (Tsybrij et al. 2017), but this has been more recently revised, based on new AMS dates, to the middle of the 6th millennium BC (Dolbunova et al. 2020b); Supplementary Materials). It was then occupied, possibly seasonally, until the Eneolithic and Bronze Age period dated to the 5th-4th millenium BC (Mazurkevich and Dolbunova 2012; Dolbunova 2016; Dolbunova et al. 2020b). Twenty-three cultural layers were identified, each of them clearly separated by sterile interlayers allowing fine chronological reconstruction. The cultural layers from 23 to 11 are attributed to the Early Neolithic phases.

Ceramic vessels recovered from the earliest cultural layers at Rakushechny Yar show variation in terms of form, volume and technology. Thirteen different vessel forms, attributed to the Early Neolithic layers, were identified constituting what we can consider a complete repertoire of 'kitchenware', encompassing plates, cooking pots, bowls (Fig. S1), all with different volumes, from tiny vessels $(<0.5 \mathrm{~L})$ to much larger containers $(15-20 \mathrm{~L})$. Pottery making therefore seems to be highly developed from the outset, consistent with models for adoption rather than independent innovation. The ceramic vessels are generally with flat bottoms and are largely undecorated (91\%). Nevertheless, pointed bottomed pottery was also found and some of the pottery was covered with red and/or yellow ochre and used as ochre containers (Mazurkevich and Dolbunova 2015). Four different chaînes opératoires were reconstructed as well as the use of various local clay sources and paste recipes reflecting the adaptation of several techniques for pottery production (Mazurkevich and Dolbunova 2012, 2015; Dolbunova 2016; Dolbunova et al. 2020a; Kulkova et al. 2018).

The well-preserved faunal assemblage reveals a subsistence economy mainly based on hunting and fishing. Wild mammals, such as red and roe deer (Cervus elaphus, Capreolus capreolus), and riverine resources including both freshwater (e.g. Cyprinidae, Wels catfish, Silurus glanis, etc.) and anadromous (e.g. sturgeon, Acipenser spp.) fish and shellfish (e.g. Unio spp. and Viviparus diluvianus) (Belanovskaya 1995; Zabilska-Kunek 2019), provided the majority of resources (Fig. 2). There is limited evidence of widespread plant exploitation, with the recovery of only one water caltrop (Trapa natans $L$.). Charcoal remains from the site are interpreted as waste from wood processing or smoking (Dolbunova et al. 2020a). The faunal assemblage consists predominantly of kitchen waste accumulated in cultural layers. Red deer were butchered on site, as testified by finds from edible and inedible parts of the body (phalanges, including hooves, antlers fragments and teeth). Nevertheless, the location of the site and the amount of fish bones and shell remains, as well as the very specific lithic and bone tool assemblage, emphasize the importance of fishing activities at Rakushechny Yar. As discussed above, putative finds of domesticated animals have been reported in the lower layers (e.g. sheep, cattle, pig; Sablin 2018; Dolbunova et al. 2020b), but these represent only ca. $11 \%$ of the mammalian assemblage (Fig. 2) otherwise dominated by wild cervids. Although the cattle and pig bones have been assigned on morphological grounds to be from domesticated stock, further DNA analysis is needed to confirm their origin and whether the common domesticated phenotypic traits are present (Verdugo et al. 2019; Frantz et al. 2019). It is important to note that domesticated cereal impressions on pottery vessels only appear in later Eneolithic layers (MotuzaiteMatuzeviciute 2012).

\section{Materials and methods}

\section{Lipid residue analysis and bulk stable isotope analysis of pottery}

Permissions were obtained to sample 120 samples (74 sherds and 46 foodcrusts) for organic residue analysis, representing 95 vessels typologically ascribed to the Early Neolithic phase. For 22 vessels permission was granted to only sample foodcrusts to minimise destruction to the vessel. The samples were obtained from early Neolithic layers N10-16, 19-21 and 23 from the older excavation made in 1966 (Belanovskaya 1995) and from the more recent excavation including Sect. 1 and on viviparus layers (1 to 3 ) in Sects. 2-3; (Table S1; see also description in Dolbunova et al. 2020a). Layers 17-15 (Sect. 1) are dated to between ca. 5600-5500 cal BC and the other Early Neolithic layers are most likely of similar date, or even slightly more recent (Dolbunova et al. 2020b). In addition, lipids of modern edible endemic fruits and plants from Rakushechny Yar's vicinity (e.g. bulrush, Typha; wild thyme, Thymus; silverberry, Elaeagnus; wild rose berry, Rosa; wild pear, Pyrus; wild apple; Malus), modern shellfish (Viviparus, Unio) from the Lower Don River, modern fish (freshwater or migratory species) and wild ruminants (e.g. reindeer, Rangifer tarandus; elk; Alces alces, roe deer) from Russia were analysed (Table S2) for comparison with the lipids derived from archaeological ceramic samples. Lipids from soil from some of the cultural layers of the site were also extracted to control any potential environmental contamination (Table S1). 
Lipids extracts were obtained for all the samples (potsherds: ca. $1 \mathrm{~g}$; foodcrusts ca. $20 \mathrm{mg}$ ) using a modified onestep acidified methanol methodology (Craig et al. 2013). When sufficient material was present, an additional solvent extraction following published protocols (Bondetti et al. $2020 \mathrm{~b})$ was performed $(n=20)$, to enable the detection of any triacylglycerols or wax esters. Lipid extracts were analysed using gas chromatography-mass spectrometry (GC-MS) with different columns and modes. For the methanolic acid extracts yielding a sufficient amount of lipids, the carbon isotope values of palmitic acid $\left(\mathrm{C}_{16: 0}\right)$ and stearic acid $\left(\mathrm{C}_{18: 0}\right)$ were obtained using gas chromatography-combustion-isotope ratio mass spectrometry (GC-C-IRMS). Elemental analysis-isotope ratio mass spectrometry analysis (EA-IRMS) was also performed on charred foodcrusts samples $(\sim 1 \mathrm{mg})$ for the determination of their stable nitrogen $\left(\delta^{15} \mathrm{~N}\right)$ and carbon $\left(\delta^{13} \mathrm{C}\right)$ isotope values, as detailed in previous publications (Craig et al. 2007; Lucquin et al. 2016b). Further information on the extraction methodologies employed here and the instrument conditions are provided in the Supplementary Materials.

\section{Digital microscopy and scanning electron microscopy (SEM)}

Where the quantity of charred foodcrusts was sufficient, digital and scanning electron microscopy was conducted to complement the lipid analysis. This approach has previously been tested and proved successful in determining the presence of plant products in foodcrusts adhered to prehistoric pottery from the Netherlands (Raemaekers et al. 2013). Seven of the 50 charred foodcrusts from Rakushechny Yar were selected for microscopic analysis (samples 915, 916, 920, 921, 926, 927 and 929); these were chosen from the samples available due to their good preservation and thicker macrostructure which provided a larger mass of material and allowed a thorough investigation of their composition. Initial observation under low-powered microscopy was carried out using a Leica MZ APO binocular microscope at magnifications of between 8 and 50x. In order to study the microstructure and physical attributes of the residues, images were created using a VHX-5000 Keyence digital microscope at magnifications from 20 to 200x. From these, food fragments that presented visible inclusions (such as putative animal or plant tissues) were selected for further study under SEM. For SEM observation, samples were cleaned from adhered materials such as clay residue and sediments with a brush and sputter coated with $c a$. 1 micron of gold when necessary for image quality purposes. These were then examined using a Hitachi S-3700 N scanning electron microscope housed at the Scientific Research Department of the British Museum. The two main aims of these analyses were to identify specific types of particles visible in the foodcrusts, such as plant and animal tissues, in order to elucidate the ingredients used, and the exploration of the foodcrusts' microstructures in order to distinguish potential processing and cooking techniques which might have led to the accumulation of these residues.

Selected fragments of foodcrusts were analysed using SEM for specific observation of the matrix/microstructure. During this, up to five images of the matrix of each fragment were captured, at 10-16 mm working distance and at $50 \times$ magnification, to cover the whole surface. Then, the visible particles were captured one by one for further identification. Identification of any tissues was carried out in comparison with modern and archaeological reference materials as well as available published data.

\section{Bulk analysis of bone collagen}

Stable isotopic analysis of bone collagen was undertaken from a range of fauna from the site to provide a broad reference with which to interpret the lipid data. Archaeological bones of deer $(n=24)$, pig $(n=7)$, beaver (Castor fiber, $n=1)$, horse (Equus ferus, $n=3)$, zander $(n=4)$ and Wels catfish $(n=1)$ from Rakushechny Yar were selected (Table S3) to serve as an archaeological isotopic reference. Bone collagen was extracted using a standard procedure developed by Longin (1971) and Brown et al. (1988) and then modified in Alexander et al. (2015). Samples were subsequently isotopically analysed by EA-IRMS akin to the foodcrust samples. Further information about the methodology is provided in the Supplementary Material.

\section{ZooMS (zooarchaeology by mass spectrometry)}

To confirm the presence of domesticated species, 18 bone samples from different layers at Rakushechny Yar were subjected to collagen peptide mass fingerprinting, also known as ZooMS. Four of the bones had been morphologically identified as sheep or goat, while the others could only be assigned to the family Bovidae or unidentified (Table S5). Frequently used in archaeology and palaeontology, ZooMS was developed by (Buckley et al. 2009) as a technique to identify collagen-based remains (i.e. bone, antler, leather) and is particularly useful for fragmented or worked remains where morphological indicators have been modified or removed. It involves peptide mass fingerprinting of Type I collagen using matrix-assisted laser desorption/ionisation time-offlight mass spectrometry (MALDI-ToF-MS). Extracted collagen peptides from a specimen are compared with known peptide markers in order to identify the source of the raw material, usually to the genus level. ZooMS was performed following a slightly modified method to that outlined in (Buckley et al. 2009), with the extracted collagen peptides analyzed on a Bruker ultraflex III MALDI-ToF-MS. Sample spectra were analysed using mMass software (www.mmass. 
org; Strohalm et al. 2008) and compared with a database of known $m / z$ markers (Buckley et al. 2009, 2010; Buckley and Collins 2011; Kirby et al. 2013). More information about the protocol and instrument conditions are available in the Supplementary Material.

\section{AMS ${ }^{14} C$ dating}

The ceramic assemblage discussed in this paper can be dated by stratigraphic association with mammal bones interpreted as food waste, which have been dated by accelerator mass spectrometry (AMS) following routine protocols. Bone identifications have been tested by ZooMS, as described above, and collagen from the dated bones analysed by EA-IRMS, providing additional isotopic reference data. A summary of relevant methods and results, and a re-evaluation of legacy

${ }^{14} \mathrm{C}$ data from Rakushechny Yar, is provided in the Supplementary Material.

\section{Results and discussion}

\section{Preservation of animal fats in Rakushechny Yar pottery}

The preservation of lipids in association with pottery from Rakushechny Yar was excellent, with $94 \%$ of the samples yielding amounts of lipids above the accepted threshold of interpretation (i.e. $>5 \mu \mathrm{g} / \mathrm{g}$ for potsherd or $>100 \mu \mathrm{g} / \mathrm{g}$ for foodcrusts) (Evershed et al. 2008a; Craig et al. 2013). Overall, the lipid profiles are characterized by a complex mixture of aliphatic compounds, encompassing saturated fatty acids ranging from $\mathrm{C}_{6: 0}$ to $\mathrm{C}_{30: 0}$, monounsaturated fatty acids $\left(\mathrm{C}_{14}-\mathrm{C}_{24}\right)$, branched fatty acids $\left(\mathrm{C}_{12}-\mathrm{C}_{19}\right)$ and dicarboxylic acids $\left(\mathrm{C}_{5}-\mathrm{C}_{15}\right)$ (Fig. S2a). Cholesterol and its derivatives were also detected in over one third of the samples. Overall, the lipid evidence points overwhelmingly to the presence of animal fats in the majority of pots from Rakushechny Yar, which could include both aquatic and terrestrial animal sources.

Only one sample (151) displayed a different molecular profile (Fig. S2b), with diterpenes typical of Pinaceae resin and wood (dehydroabietic acid, methyl-dehydroabietic acid and 7-oxo-dehydroabietic acid) along with traces of retene characteristic of thermal treatment (Colombini et al. 2005; Modugno and Ribechini 2009). The absence of methyl-dehydroabietic acid in the solvent-extracted extracts seems to support the use of resin rather than the processing of resinous pine wood (Modugno and Ribechini 2009). Interestingly, this vessel had a very specific elongated form (Fig. S3), similar to 'oil lamps' recovered from hunter-gatherer Baltic contexts (Heron et al. 2013). Whilst these compounds can arise from environmental contamination (Naihuang et al.
1995; Costa et al. 2016), the absence of such markers in the sediments collected at Rakushechny Yar does not favour this interpretation. Interestingly, anthracological analyses of the charcoals recovered from the site revealed the non-use of pine as firewood, favouring instead other wood species (e.g. Salix sp. willow and/or Populus sp. poplar) (Dolbunova et al. 2020a). The detection of Pinaceae markers in this pottery might suggest particular usages of pine wood. Pinaceae resin may have had various functions in prehistory, as an adhesive, a disinfectant or as a waterproofing agent (Regert 2004; Mitkidou et al. 2008; Rageot 2015; Rageot et al. 2021). However, from its form, the vessel could have been used for burning conifer resin for its odiferous properties, i.e. as an incense (Lucquin et al. 2007) or conceivably as an insect repellent. Interestingly, no aquatic-derived lipids were detected in this sample which contrasts with the western Baltic examples that were mainly used for the burning of aquatic oils (Heron et al. 2013).

\section{Molecular and isotopic evidence for aquatic resources in pottery}

The stable carbon isotope values of the two most abundant unsaturated fatty acids $\left(\mathrm{C}_{16: 0}\right.$ and $\left.\mathrm{C}_{18: 0}\right)$ were measured for 112 samples in order to provide further information regarding contents. The $\Delta^{13} \mathrm{C}\left(\delta^{13} \mathrm{C}_{18: 0}-\delta^{13} \mathrm{C}_{16: 0}\right)$ value avoids environmental influences on the absolute $\delta^{13} \mathrm{C}$ values (Copley et al., 2005) and has been widely used to discriminate ruminant adipose and dairy fats from other nonruminant sources (e.g. Craig et al. 2012, 2013; Cramp et al. 2014; Taché and Craig 2015; Colonese et al. 2015; Lucquin et al. 2016b). These values are plotted against $\delta^{13} \mathrm{C}_{16: 0}$ in Fig. 3a. At Rakushechny Yar, over $85 \%$ of the samples have non-ruminant lipid isotope signatures. Considering the faunal assemblage at Rakushechny Yar, non-ruminant sources could include aquatic or non-ruminant terrestrial animals, such as pig, beaver or horse.

A total of 64 samples, corresponding to $56 \%$ of the vessels analysed, contained diagnostic compounds for aquatic foods, either including $\omega$-(o-alkylphenyl)alkanoic acids (APAAs) containing 20 or more carbon atoms alongside at least one isoprenoid acid (either 4,8,12-trimethyltridecanoic acid, phytanic or pristanic acid (Evershed 2008; Hansel and Evershed 2009; Cramp and Evershed 2014), or a contribution of SRR-isomer of phytanic acid $>75 \%$. APAAs arises from the heating (at least $1 \mathrm{~h}$ of heating at a temperature $\geq 200{ }^{\circ} \mathrm{C}$; (Bondetti et al. 2020c) of their precursor long-chain unsaturated fatty acids, which occur only in an appreciable amount in freshwater and marine animals (Hansel et al. 2004; Evershed et al. 2008a) and constitute, therefore, an important marker for the cooking of aquatic source fats in pots. 

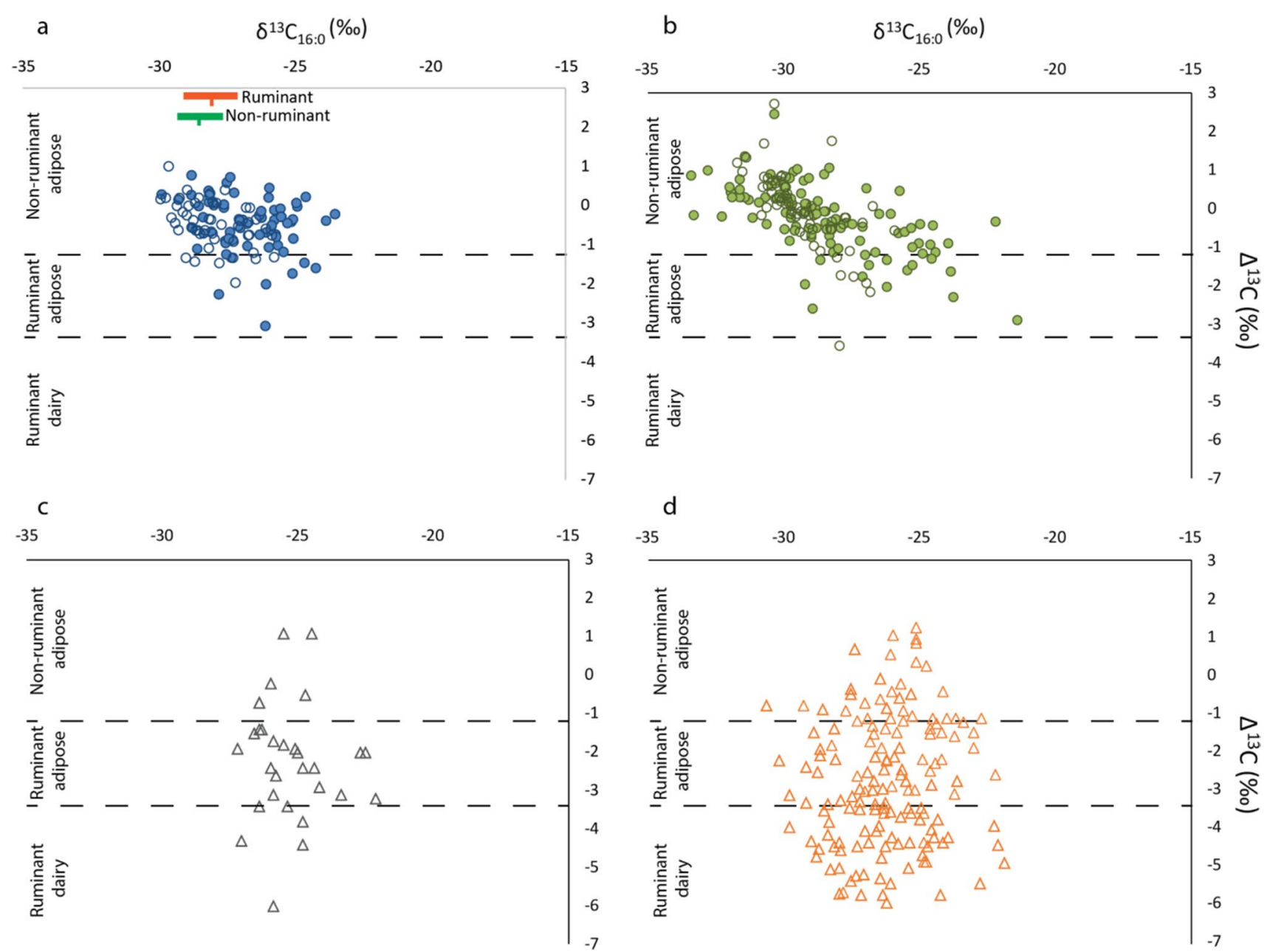

Fig. 3 Plot of $\Delta^{13} \mathrm{C}$ values against $\delta^{13} \mathrm{C}_{16: 0}$ values of (a) Rakushechny Yar samples compared with pottery from (b) Zamostje 2 site (Bondetti et al. 2020b) and early agricultural sites in (c) Syria (Nieuwenhuyse et al. 2015) and (d) Anatolia (Evershed et al. 2008b; Debono Spiteri et al. 2016). For (a) and (b) plots, the filled circles indicate samples with aquatic signals. For (c) and (d) aquatic derived lipids are not reported but presumed to be absent. The data generated here are com-

Whilst APAA- $\mathrm{C}_{20}$ are also produced by heating terrestrial mammals and plants, the relative abundance of these compounds is much greater in processed aquatic products (Bondetti et al. 2020c). The calculation of the relative abundance of APAA- $\mathrm{C}_{20}$ vs. $\mathrm{C}_{18}$ provides a new criterion for identifying whether these compounds arose from the processing of aquatic or terrestrial commodities. Rakushechny Yar samples overall display a high APAA $\mathrm{C}_{20} / \mathrm{C}_{18}$ ratio $(\bar{x}=0.23 \pm 0.10)$ consistent with values from authentic fish (>0.06). Likewise, although phytanic acid occurs both in the tissues of aquatic and ruminant animals, the ratio of the phytanic diastereomers (3S,7R,11R,15-phytanic acid [SRR], and 3R,7R,11R,15-phytanic acid [RRR]) provides an additional tool to distinguish these sources (Lucquin et al. 2016a). A greater contribution of SRR-isomers (i.e. > 75\%)

pared with the mean and ranges $(2 \sigma)$ of expected lipid $\delta^{13} \mathrm{C}$ values, based on bone collagen of archaeological non-ruminant (including pig and beaver) and ruminant (red deer) recovered at Rakushechny Yar, plotted on the $\mathrm{x}$-axis only. The collagen $\delta^{13} \mathrm{C}$ values were adjusted by $-8 \%$ o to correct for the collagen to tissue offset in order to make these values comparable with $\delta^{13} C_{16: 0}$ of lipids extracted from pottery (Fernandes et al. 2015)

is usually ascribed to aquatic species (Lucquin et al. 2016a). A further 20 samples contained $\mathrm{C}_{18}$ APAAs and at least one isoprenoid or an SRR\% between 65.6 and 75.5\% (Table S1), indicating that aquatic resources were most likely processed in these vessels as well (Evershed et al. 2008a; Heron et al. 2015; Lucquin et al. 2016b), although definitive evidence is lacking.

The other samples falling in the non-ruminant isotopic value area, without aquatic biomarkers, might either result from the degradation of these specific molecules or could also reflect the processing of non-ruminant terrestrial products rather than aquatic resources. These samples tend to have fatty acids more depleted in ${ }^{13} \mathrm{C}\left(\delta^{13} \mathrm{C}_{16: 0}=-28.3 \pm 0.9 \%\right.$; $\delta^{13} \mathrm{C}_{18: 0}=-28.6 \pm 0.7 \%$ ) than samples with aquatic biomarkers $\left(\delta^{13} \mathrm{C}_{16: 0}=-26.7 \pm 1.4 \%\right.$; $\delta^{13} \mathrm{C}_{18: 0}=-26.9 \pm 1.4 \%$; 
Mann-Whitney test: $\mathrm{U}=193 ; \mathrm{z}=4.3 ; p<0.01$ for $\delta^{13} \mathrm{C}_{16: 0}$ and $\mathrm{U}=144 ; \mathrm{z}=4.9 ; p<0.01$ for $\delta^{13} \mathrm{C}_{18: 0}$ ) in keeping with measurements made on collagen from beaver, horses and pigs from the site (Fig. 3a, Table S3) after a-8\%o collagen to lipid offset has been applied (Fernandes et al. 2015). Nevertheless, in the absence of further diagnostic lipids, a more precise identification of non-ruminant terrestrial sources cannot be clearly established.

The $\delta^{13} \mathrm{C}_{16: 0}$ and $\delta^{13} \mathrm{C}_{18: 0}$ values of Rakushechny Yar samples are plotted in Fig. 4a. These have a wide range of $\delta^{13} \mathrm{C}$ isotopic values varying between -23.5 and $-30.3 \%$. Whilst some samples have fatty acid $\delta^{13} \mathrm{C}$ values corresponding to the reported range for modern authentic freshwater fish oils (Fig. 4a), the majority have more positive $\delta^{13} \mathrm{C}$ values outside this range. These are more consistent with values expected from anadromous or marine fish (Craig et al. 2011, 2013; Pääkkönen et al. 2016; Lucquin et al. 2016b; Choy et al. 2016). Given the site's location, some distance from the Sea of Azov and Black Sea (ca. 100 and $500 \mathrm{~km}$ from Rakushechny Yar site, respectively), the residues in the pottery are most likely attributed to anadromous fish, such as sturgeon, than marine species. Anadromous fish spend most of their lives in the sea and ocean and migrate into riverine habitats to spawn (Zydlewski and Wilkie 2012). Therefore adult anadromous fish, having fed mainly in the marine environment, maintains a relatively enriched $\delta^{13} \mathrm{C}$ signature even when caught up-river (McCarthy and Waldron 2000). Sturgeons are the third most represented species in the fishbone
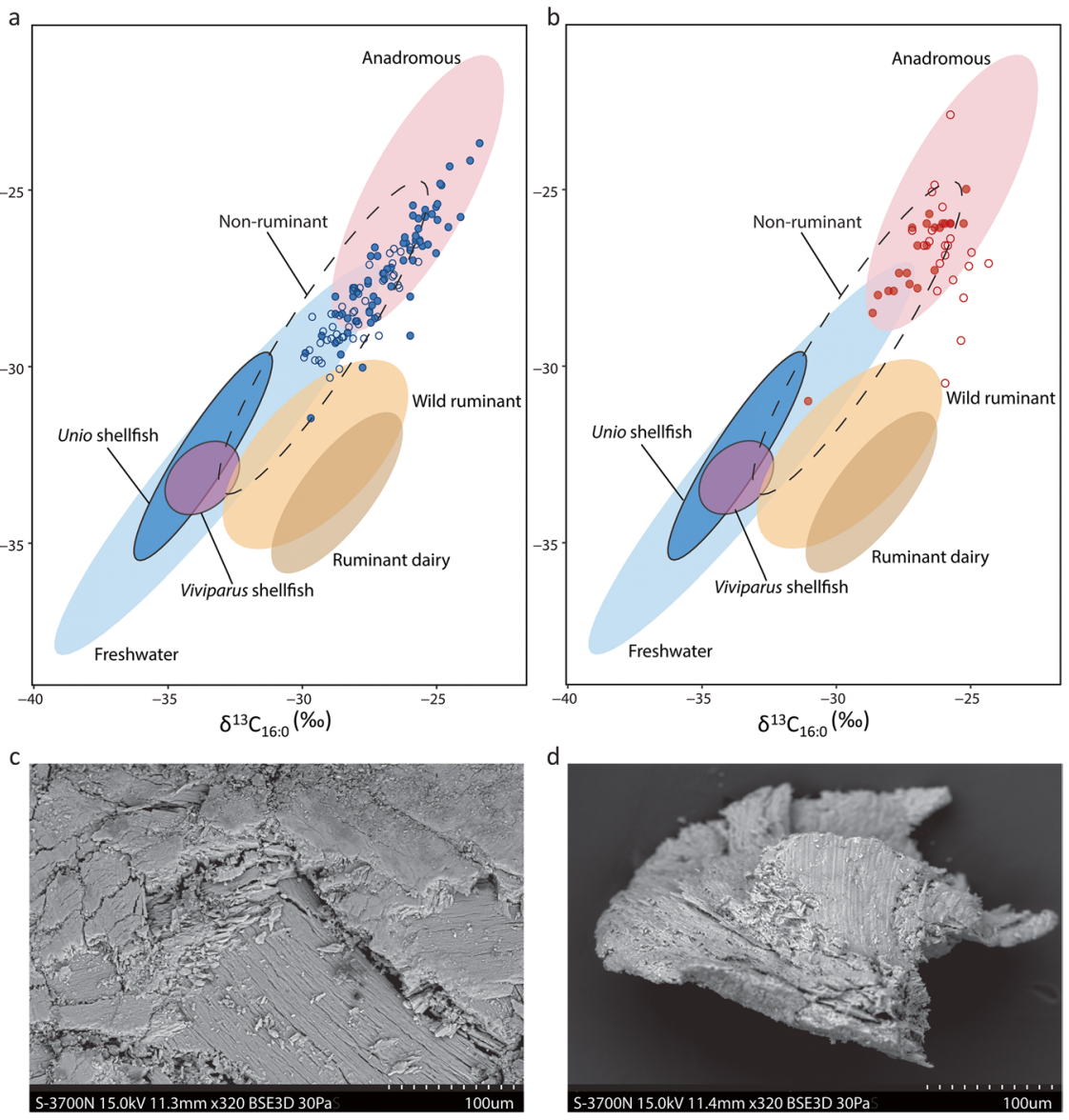

Fig. 4 Plot of the $\delta^{13} \mathrm{C}$ values of $\mathrm{C}_{16: 0}$ and $\mathrm{C}_{18: 0} n$-alkanoic acids extracted from (a) Rakushechny Yar pottery from Early Neolithic layers and (b) Iron Gates region ceramic vessels (Cramp et al. 2019). SEM micrographs showing fragments of sturgeon bony components (c) in a foodcrust sample from Rakushecnhy Yar (Raku-929) and (d) of archaeological sturgeon reference materials. Samples with aquatic biomarkers are shown by filled circles. The data are compared with reference ranges for authentic reference lipids from modern tissues from published studies (Dudd 1999; Spangenberg et al. 2006; Outram et al. 2009; Craig et al. 2011, 2012, 2013; Taché and Craig 2015;
Pääkkönen et al. 2016, 2020; Lucquin et al. 2016b; Choy et al. 2016; Courel et al. 2020) and additional new Unio and Viviparus shellfish data from the Low Don River and freshwater fish and ruminants from Russia (95\% confidence; Table S2). To allow comparison with the archaeological samples from the Holocene period, the $\delta^{13} \mathrm{C}$ values of the modern samples were adjusted given the variation in the atmospheric $\delta^{13} \mathrm{C}$ resulting from post-industrial carbon according to the known or estimated year of death of the animal (Hellevang and Aagaard 2015) 
assemblage (Zabilska-Kunek 2019). Conversely, pots with relatively depleted ${ }^{13} \mathrm{C}$ are more in keeping with freshwater fish such as cyprinids (Cyprinidae) and Wels catfish (Silurus glanis), constituting the major part of the fish remains in Rakushechny Yar (Zabilska-Kunek 2019), or even juvenile sturgeon which would still provide a more freshwater signal (Doucett et al. 1999).

To test these assumptions, we examined $\delta^{13} \mathrm{C}$ collagen values of fish present in the assemblages and reported in the literature. A correction of $-7 \%$ was applied to the collagen values to allow comparison with lipid values (Fernandes et al. 2015). The mean adjusted carbon isotopic value obtained from non-migratory freshwater fish recovered at Rakushechny Yar (catfish and zander) is $-28.5 \% \circ( \pm 3 \% \circ ; n=5$; Table S3). While this is consistent with the more depleted range of lipid $\delta^{13} \mathrm{C}$ values obtained from pottery at Rakushechny Yar, one zander had a much more positive $\delta^{13} \mathrm{C}$ value (Table S3). There was insufficient collagen in the sturgeon bones from Rakushechny Yar for analysis, but collagen isotope data from sturgeon bones from the Danube Gorges or Central Balkan sites show generally more positive $\delta^{13} \mathrm{C}$ values after applying the lipid to collagen correction $(\bar{x}=-26.6 \pm 1.2 \% ; n=4$; Borić et al. 2004; Jovanović et al. 2019) than freshwater species, although their ranges overlap.

A small proportion of samples contained aquatic lipids that could also be derived from the beaver fats (Fig. 4a, Table S2) based on their fatty acid $\delta^{13} \mathrm{C}$ values. Beavers were exploited at Rakushechny Yar but only form a minor part of the faunal assemblage (Fig. 2). As with aquatic organisms, beaver fats are characterised by high amounts of phytanic acid with a very significant contribution of the SRR-isomer $(\bar{x}=98.5 \pm 2.9 \%)$ (Table S4) and APAAs $C_{20}$ are produced when subjected to thermal treatment (Bondetti et al. 2020c). Nevertheless, the relatively high APAA $\mathrm{C}_{20}$ / $\mathrm{C}_{18}$ ratio obtained from the Rakushechny Yar pottery precludes beavers, which exhibit a much lower value $(<0.06)$ (Bondetti et al. 2020c) and are instead consistent with fish or aquatic molluscs.

The homogeneity of the residues at Rakushechny Yar is intriguing, given the typologically diverse pottery assemblage analysed, which ranges from very small vessels $(<0.5 \mathrm{~L})$ to large containers $(15-20 \mathrm{~L})$ with a wide range of thicknesses (Table S1). There was no statistical difference between the frequency of aquatic biomarkers when the data are disaggregated according to different volume categories, and there was no correlation with vessel wall thickness. When paired samples (charred foodcrusts and associated ceramics) are considered, the presence/absence of aquatic biomarkers are in accordance for $74 \%$ of the cases $(n=23)$. The isotopic values between charred foodcrusts and their associated ceramics are moderately correlated (Pearson: $\mathrm{R}=0.67 ; p<0.01$ for $\delta^{13} \mathrm{C}_{16}$ and $\mathrm{R}=0.53$; $p<0.01$ for $\left.\delta^{13} \mathrm{C}_{18}\right)$, with no systematic offset $\left(\delta^{13} \mathrm{C}_{\mathrm{FA}}\right.$ foodcrusts $-\delta^{13} \mathrm{C}_{\mathrm{FA}}$ sherd; $\delta^{13} \mathrm{C}_{16}$ offset $=-0.36 \pm 1.29$, $\mathrm{s}^{2}=1.67(1 \sigma)$ and $\delta^{13} \mathrm{C}_{18}$ offset $=-0.56 \pm 1.56(1 \sigma)$, $\left.\mathrm{s}^{2}=2.44\right)$. Most likely, the ceramic matrix sample represents an accumulated lipid signal derived from multiple uses of the vessel where the foodcrusts represents more episodic cooking events, as suggested by long-term cooking experiments (Miller et al. 2020). Therefore, here we consider the ceramics matrix and foodcrusts as individual 'samples' representative of different 'cooking events'. Whilst slight differences in the individual cooking events can be noted, the commodities processed appear to be similar overall (mean $\delta^{13} \mathrm{C}_{16}=-27.11 \pm 1.46 \%$ o $(1 \sigma)$ for foodcrusts and mean $\delta^{13} \mathrm{C}_{16}=-27.47 \pm 1.66 \%$ o $(1 \sigma)$ for ceramic; mean $\delta^{13} \mathrm{C}_{18}=-27.46 \pm 1.64 \%$ o $(1 \sigma)$ for foodcrusts and mean $\delta^{13} \mathrm{C}_{18}=-28.02 \pm 1.57 \%$ ( $(1 \sigma)$ for ceramic; T-test: $\mathrm{t}=0.78$, $p=0.44$ for $\delta^{13} \mathrm{C}_{16}$ and $\mathrm{t}=1.20, p=0.24$ for $\delta^{13} \mathrm{C}_{18}$ ) supporting our inference of specialist 'aquatic' use of the pottery over its entire use-life.

Additionally, the bulk stable nitrogen $\left(\delta^{15} \mathrm{~N}\right)$ and carbon $\left(\delta^{13} \mathrm{C}\right)$ isotope values of foodcrusts adhering to the ceramic vessels were measured. Figure 5a shows the $\delta^{15} \mathrm{~N}$ values of foodcrusts plotted against the $\mathrm{C} / \mathrm{N}$ ratios. Six samples have relatively higher $\mathrm{C}: \mathrm{N}$ ratios (i.e. $>20$ ) along with $\delta^{15} \mathrm{~N}$ values above $+10 \%$, which is consistent with fish oil (Dufour et al. 1999; Heron et al. 2013; Craig et al. 2013; Choy et al. 2016). Interestingly, these samples and the pottery sherds they were associated with, have relatively enriched $\delta^{13} \mathrm{C}$ and previously ascribed to anadromous fish fats $\left(\delta^{13} \mathrm{C}_{16: 0}=-25.7 \pm 0.9 \%\right.$ o and $\delta^{13} \mathrm{C}_{18: 0}=-26.1 \pm 1.1 \%$ ) with over $85 \%$ of them having aquatic biomarkers (Fig. 5b). In addition, many of the foodcrusts exhibiting anadromous signature had a microscopically observable thin and oily microstructure also consistent with high-temperature processing and oil extraction.

The rendering of fish to produce storable oils would have helped to deal with the seasonal surplus of migratory sturgeon, available only during the late spring (Kovalchuk et al. 2018). Sturgeon, which can reach several hundred kilograms, likely constituted an important and valued source of food for prehistoric communities. Indeed, their flesh and roe are rich in fat and protein (Badiani et al. 1996; Ovissipour and Rasco 2011). Rendered oils could be stored and consumed during the colder seasons when resources were more scarce, but could also be accumulated and exchanged, in order to buffer risk but leading to the creation of ownership, debts and inequalities and social hierarchies (Hayden 2009). Other traditional non-culinary uses of fish products include collagen extraction for making glue and tanning of skins to make leather, all of which would have been valuable commodities (Jackinsky-Sethi 2014). The near absence of use-wear traces on the vessels suggests that they were not used for daily household activities but most likely for specialist activity during short-lived seasonal periods, 


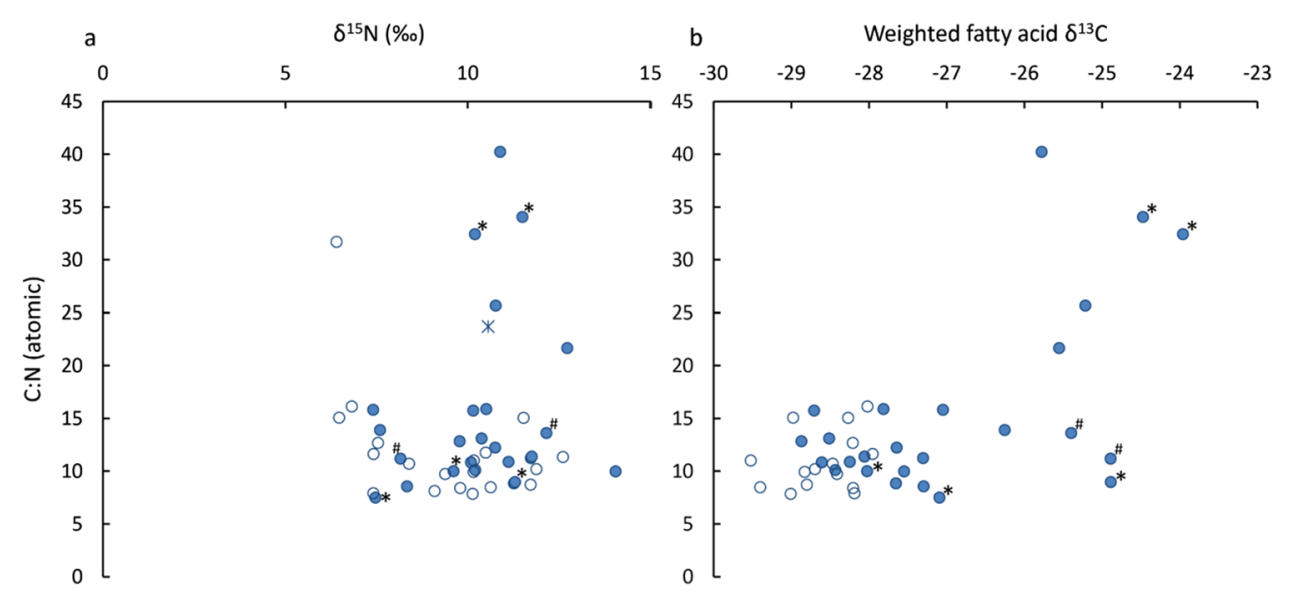

Fig. 5 Plot of (a) $\delta^{15} \mathrm{~N}$ against $\mathrm{C} / \mathrm{N}$ ratio and (b) weighted fatty acid $\delta^{13} \mathrm{C}$ against $\mathrm{C} / \mathrm{N}$ ratio obtained from Rakushechny Yar foodcrust samples of which fatty acids were available. Filled circles indicate samples with aquatic biomarkers, * represents samples where sturgeon osseous structures were detected by SEM, and \#

although comparative experimental material would be needed to test this hypothesis.

The faunal remains at Rakushechny Yar also point to an extensive accumulation of shellfish, namely, Viviparus diluvianus and Unio (Dolbunova et al. 2020b). Although the natural or anthropogenic nature of Viviparus shells presence is unclear due to the current lack of research on them, several evidences indicate that the Unio shells have been widely used for various technological purposes (e.g. for the construction of platforms, as scraping tools and ochre containers), but they were also consumed potentially in large quantities. Given that an efficient way to extract mollusc meat from their shell is by boiling (Miracle 2002; Milner 2009), it is worth considering whether ceramic containers were used to facilitate this task, as has been suggested for Jōmon pottery in Japan (Ikawa-Smith 1976). However, the isotope values obtained from modern shellfish (Unio and Viviparus diluvianus) harvested in the Don River nearby Rakushechny Yar and corrected for the Suess effect (Hellevang and Aagaard 2015) rule out this hypothesis as their fatty acids are more depleted in ${ }^{13} \mathrm{C}$ compared with those from the vessels (Fig. 4a). Instead, alternative methods may have been used for processing prior to consumption. In this sense, the discovery of a pit filled with burnt shell remains at Rakushechny Yar might suggest it was used as an oven for this purpose (Aldeias et al. 2019; Dolbunova et al. 2020b).

Similarly, ruminant animals make a significant contribution to the mammalian faunal assemblage but less than $15 \%$ of the ceramic samples have fatty acids with a ruminant stable carbon isotope signature $\left(\Delta^{13} \mathrm{C}\right.$ values $<-1$; Fig. 3a). Over half of these samples contain aquatic biomarkers. A likely explanation is that ruminant carcass fats and fish oils were mixed in these pots. Bondetti et al. (2020a) and represents samples where cyprinid and sturgeon osseous structures were observed. The weighted fatty acid $\delta^{13} \mathrm{C}$ corresponds to the weighted average carbon isotope value based on the relative proportion of $\mathrm{C}_{16: 0}$ and $\mathrm{C}_{18: 0}$ fatty acids, as reflected in the $\mathrm{P} / \mathrm{S}$ ratio $\left(\left[\delta^{13} \mathrm{C}_{16: 0} \times \mathrm{P} / \mathrm{S}+\delta^{13} \mathrm{C}_{18: 0}\right] /[\mathrm{P} / \mathrm{S}+1]\right)$

others (Cramp et al. 2019) have shown that negative $\Delta^{13} \mathrm{C}$ values are theoretically observed when fish oils are mixed with even a modest (ca.>10\%) amount of ruminant fats due to differences in the fatty acid concentrations between these products. Furthermore, some of these samples exhibit more enriched $\delta^{13} \mathrm{C}$ values than archaeological and modern wild-ruminants from Rakushechny Yar and Western Russia, respectively, also indicating that they were mixed with anadromous fish (Fig. 3a; Table S3). Overall, therefore ruminant carcass fats seem to be only a minor addition to culinary practices involving cooking pots at Rakushechny Yar.

\section{Digital microscopy and scanning electron microscopy}

Analysis of foodcrusts by scanning electron microscopy (SEM) showed thin and compacted microstructure formed by vitrified shiny layers of charred matter. Interestingly, the appearance of the microstructure contrasts with previous analysis of charred material interpreted to be derived from boiling plant foods (Gonzalez Carretero et al. 2017; Gonzalez Carretero 2020), which tend to be more porous, suggesting a different mode of use as noted above. Particles with variable degrees of charring were clearly visible embedded in this microstructure. All seven of the analysed foodcrusts were seen to contain small fragments of sturgeon bony structures. In most cases, these were found to be derived from dermal scutes as they had a laminated microstructure typical of this type of bony tissue. In addition, potential fragments of sturgeon fin spine bones or round based scales have been identified in a single foodcrust, from sample 926 . Fragments of sturgeon bones appeared embedded in the foodcrusts' microstructures and their preservation differed 
from completely charred to non-charred. These were seen to measure between $c a .50 \mu \mathrm{m}$ and $1000 \mu \mathrm{m}$ in size and presented a clear laminated microstructure formed by a grid of parallel tubes forming horizontal bony layers as seen from modern and archaeological sturgeon reference materials (Hilton et al. 2011; Thieren et al. 2015; Figs. 4c and d). Positive identification of these remains as fragments of sturgeon bone structures was possible through the comparison with reference sturgeon bones, in particular lateral scutes and fin fragments. Reference materials were provided by Museum of London Archaeology (MOLA).

In addition to the remains of sturgeon bony structures, foodcrusts from samples 915 and 921 were seen to contain remains of partially preserved soft-edged (cycloid) fish scales. Based on the observation of typical morphological traits (Esmaeili et al. 2007), these are believed to belong to members of the cyprinid family (e.g. common bream, Abramis brama, carp, Cyprinus carpio, asp, Aspius aspius or tench, Tinca tinca) widely present in the archaeological fish bone assemblage at the site (Zabilska-Kunek 2019). In contrast to cyprinids, the other types of fish recovered from the archaeological record at Rakucheshny Yar, such as Wels catfish and sturgeon, have scale-less bodies. In the case of Wels catfish, their bodies are covered in a slime-like substance which is invisible in the archaeological record.

In contrast with the high proportion of fish, microscopic analysis of the selected samples has shown no clear evidence of any other animal products being used. Potential plant tissues were identified in three of the seven foodcrusts analysed. Although not well enough preserved to allow identification to type or genus level, these have similar appearances to some of the tissues contained in the epidermis of grasses, such as the cells of the aleurone layer containing what looks like aleurone protein. This is specifically seen in samples 920, 926 and 927.

\section{Were domesticated animals introduced with pottery at Rakushechny Yar?}

No dairy fats were detected in any of the pottery vessels from Rakushechny Yar (Fig. 3a and 4a). All the $\Delta^{13} \mathrm{C}$ values are above the range for modern dairy reference fats $(-3.3 \%$; Fig. 3a). Other clear molecular indicators of dairy, such as lower molecular weight triacylglycerols, were also absent. Twenty-five samples exhibited short-chain fatty acids $\left(\mathrm{C}_{6: 0}\right.$ to $\mathrm{C}_{12: 0}$ ) (Table S1) characteristic of milk fats (Christie 1989; Dudd et al. 1998; Copley et al. 2003), although these most likely reflect the degradation of longer free fatty acids through thermal or catalytic cracking, or by bacterial action (Shimoyama et al. 1993; Raven et al. 1997). The absence of dairy contrasts sharply with the results of residue analysis of pottery from agricultural Early Neolithic sites in southwest Asia, which contained a high proportion of ruminant dairy and fat products (Evershed et al. 2008b; Nieuwenhuyse et al. 2015; Debono Spiteri et al. 2016; Fig. 3c and d).

Although the obtained results cannot rule out the presence of domesticated ruminant carcass fats in the pottery, these were likely to have been a minor contribution and are most likely derived from wild ruminants, in particular cervids, that dominate the mammalian bone assemblage (Belanovskaya 1995; Dolbunova et al. 2020b). The pattern of pottery use at Rakushechny Yar instead resembles other hunter-gatherer examples, such as Zamostje 2 in the Upper Volga (Fig. 3b) and the Estonian Narva culture (Oras et al. 2017), focused on aquatic resources, notably fish.

Given the absence of any clear evidence for domesticated animal products in the pottery from Rakushechny Yar, it was important to establish whether any domesticated species were present in the Early Neolithic faunal assemblage. Of the 18 samples of bones subjected to ZooMS analysis, only three could be assigned to sheep or goat (Table S5). One of these, recovered from upper layers (upper vivip layer 1) failed to produce an AMS date, but is derived from layers with other bones that were directly dated to the 3rd millennium BC, so could not be assigned to the Early Neolithic. A goat tooth, from an unclear context, was dated to 80-250 cal AD (SUERC-94517, 1855 \pm 31 BP) (Table S6) and is the most recent dated remains so far at Rakushechny Yar. Finally, a bone identified as sheep/goat from the vivip 2 layer was dated to the Late Neolithic/Eneolithic period (SUERC-94518, 5433 \pm 31 BP, 4350-4240 cal BC). Conversely, two samples from the Early Neolithic layers (15a and 17) and directly dated to the 6th millennium BC, initially morphologically identified as sheep, were revealed to be deer through ZooMS; deer are clearly distinguishable from sheep, with the peptide Col1AT40 displaying a $\mathrm{m} / \mathrm{z}$ of 1550.8 instead of 1580.8 for the latter (Buckley et al. 2009).

Consequently, there is no secure identification of any domesticated animals in the early phases of ceramic use at Rakushechny Yar. Based on our current knowledge, Rakushechny Yar should therefore be considered as an entirely forager site during the Early Neolithic. It should be noted however that only a relatively small area along the shoreline at Rakushechny Yar has so far been excavated $\left(c a .90 \mathrm{~m}^{2}\right)$ with little evidence for habitation structures.

\section{A clear boundary between the aquatic and agricultural Neolithic?}

Both microscopy and chemical analysis of vessels from the Early Neolithic layers at Rakushechny Yar clearly shows a very strong association with fishing activities, particularly the processing of migratory fish, such as sturgeon. While some typological and stylistic details can be attributable to Early Neolithic agricultural settlements to the south and east, there is no evidence that the agricultural or pastoral economy 
was adopted at this site, as has previously been suggested (Belanovskaya 1995; Sablin 2018; Dolbunova et al. 2020b). Nevertheless, it is still plausible that knowledge of pottery production was gained through contact with farming communities but incorporated into an entirely fisher-hunter-gatherer economy. The other hypotheses are that early farmers moved to this region but abandoned food production in favor of intensive aquatic resource exploitation and adapted the use of pottery accordingly or that pottery production was innovated locally or was acquired from other foragers. Each of these hypotheses demands further investigation, particularly more precise ${ }^{14} \mathrm{C}$ dating of sites, investigation of the dispersal dynamics and comparative typological assessment, on a regional and super-regional scale.

In particular, the potential acculturation of farmers into a foraging lifeway is gaining increasing traction through studies of this nature and should no longer be considered as anomalous. In the Iron Gates Gorge and in Southern Scandinavia, residue analysis has shown that Early Neolithic Starcevo and Funnel-beaker farming communities clearly turned their potcraft towards the processing of aquatic resources in addition to dairy and other produced foods (Craig et al. 2011; Cramp et al. 2019; Fig. 4b). Many of these sites were previously occupied in the Mesolithic and are situated along rivers, lakes and coasts with high aquatic productivity, particularly in seasonal aquatic foods.

It has been argued that agriculture, pastoralism and intensive fishing are delayed-return economies that require similar technological adaptations, including pottery, in anticipation of a predictable resource, and led to similar outcomes in terms of reducing mobility, and population growth (Oras et al. 2017). The evidence from Rakushechny Yar fits well with this model, given the seasonal nature of sturgeon exploitation. Careful advanced preparation would be needed to efficiently exploit this resource, including provision for processing and storage, prompting the need for pottery production. Ethnographic studies on native communities of coastal British Columbia show that different sizes of containers were used for the rendering oil from anadromous fish (Kuhnlein et al. 1982). This may also be the case for Rakushechny Yar where a diverse range of pottery containers were used to process aquatic products to maximize returns from this seasonal resource and perhaps facilitate its long-term storage and transportation. Evidence from the appearance of the charred deposits and their elemental composition further supports oil production as a likely function.

Finally, we found no evidence at Rakushechny Yar that the boundary between the aquatic and agricultural Neolithic was 'permeable'. Perhaps the most likely hypothesis is that these semi-sedentary communities held very different world views and life-ways, which translated into separate notions regarding pottery production and usage. Investigations of pottery use and detailed archaeozoological analyses at other points of potential contact along the forager/farmer border are needed to confirm whether this pattern is sustained interregionally. Indeed, widespread analysis of 5th millenium BC forager pottery from the Baltic points to some exchange of produce between forager and farmers, at least in the western extreme prior to the wholescale adoption of farming (Courel et al. 2020).

Supplementary Information The online version contains supplementary material available at https://doi.org/10.1007/s12520-021-01412-2.

Acknowledgements We thank Frits Steenhuisen (Arctic Centre), who produced the map for Figure 1b, Marise Gorton (University of Bradford) for undertaking the bulk stable isotope analyses, Matthew Von Tersch (BioArCh) for his assistance with aspects of the laboratory work and Harry Robson (BioArCh) for his insightful comments on the paper. This research was supported by the European Union EU Framework Programme for Research and Innovation Horizon 2020 under Marie Curie Actions Grant Agreement No 676154 (ArchSci2020 program) and the ERC Advanced Grant INDUCE (The Innovation, Dispersal and Use of Ceramics in NE Europe, ERC-ADG-2015 No 695539).

Authors' contributions $\mathrm{OEC}, \mathrm{MB}, \mathrm{CH}$ and $\mathrm{ED}$ designed the research. $\mathrm{MB}$ and ED undertook the sampling. MB undertook the lipid residue and bone collagen analysis. LGC undertook the SEM and other microscopy analyses. KM and SP undertook the ZooMS analysis. JM led on dating and chronology. PJ, VT, AT, AM and $\mathrm{CH}$ providing contextual information. $\mathrm{MB}, \mathrm{AL}$ and $\mathrm{OEC}$ worked on the interpretation of the lipid residue analysis. $\mathrm{MB}$ and $\mathrm{OEC}$ wrote the manuscript with contributions from all authors.

Funding This research was supported by the European Union EU Framework Programme for Research and Innovation Horizon 2020 under Marie Curie Actions Grant Agreement No 676154 (ArchSci2020 program) and the ERC Advanced Grant INDUCE (The Innovation, Dispersal and Use of Ceramics in NE Europe, ERC-ADG-2015 No 695539).

Availability of data and material The authors confirm that the data supporting the findings of this study are available within the article and its supplementary materials.

Code availability Non applicable.

\section{Declarations}

Conflict of interest We confirm that this manuscript has not been published elsewhere and is not under consideration by another journal. The authors have no conflicts of interest to declare that are relevant to the content of this article.

Open Access This article is licensed under a Creative Commons Attribution 4.0 International License, which permits use, sharing, adaptation, distribution and reproduction in any medium or format, as long as you give appropriate credit to the original author(s) and the source, provide a link to the Creative Commons licence, and indicate if changes were made. The images or other third party material in this article are included in the article's Creative Commons licence, unless indicated otherwise in a credit line to the material. If material is not included in the article's Creative Commons licence and your intended use is not permitted by statutory regulation or exceeds the permitted use, you will 
need to obtain permission directly from the copyright holder. To view a copy of this licence, visit http://creativecommons.org/licenses/by/4.0/.

\section{References}

Alexander MM, Christopher MG, Alejandra G, Andrew RM (2015) Diet, Society, and Economy in Late Medieval Spain: Stable Isotope Evidence from Muslims and Christians from Gandía. Valencia Am J Phy Anthropol 156:263-273. https://doi.org/10. 1002/ajpa.22647

Aldeias V, Gur-Arieh S, Maria R et al (2019) Shell we cook it? An experimental approach to the microarchaeological record of shellfish roasting. Archaeol Anthropol Sci 11:389-407. https:// doi.org/10.1007/s12520-016-0413-1

Badiani A, Anfossi P, Fiorentini L et al (1996) Nutritional Composition of Cultured Sturgeon (Acipenserspp.). J Food Compost Anal 9:171-190. https://doi.org/10.1006/jfca.1996.0024

Barnes GL (1999) The Rise of Civilization in East Asia: The Archaeology of China. Thames and Hudson, Korea and Japan

Belanovskaya, (1995) Iz drevneishego proshlogo Nizhnego Podon'ya: Poselenie vremeni neolita i eneolita Rakushechnyi Yar. Izdatel'stvo S-Peterburgskogo universiteta, SPb ([In Russian])

Bērzin̄š V (2010) Finishing seasonality and techniques in prehistory: why freshwater fish are special. Archaeologia Baltica 32:37-42

Biagi P, Gratuze B, Kiosak DV et al (2014) The Neolithic obsidians from southeastern Ukraine: first characterization and provenance determination. Anadolu/ Anatolia 40:1-20

Bobrinskoy N, Kuznetzov B, Kuzyakin A (1944) Mammals of URSS. Government publishing office "Sovietaskaya Nauka," Moscow [In Russian]

Bondetti M, Lucquin A, Savel'ev NA, et al (2020a) Resource processing, early pottery and the emergence of Kitoi culture in CisBaikal: Insights from lipid residue analysis of an Early Neolithic ceramic assemblage from the Gorelyi Les habitation site. East Siberia Archaeol Res Asia 24:100225. https://doi.org/10.1016/j. ara.2020.100225

Bondetti M, Scott S, Lucquin A et al (2020b) Fruits, fish and the introduction of pottery in the Eastern European plain: Lipid residue analysis of ceramic vessels from Zamostje 2. Quat Int 541:104114. https://doi.org/10.1016/j.quaint.2019.05.008

Bondetti M, Scott E, Courel B et al (2020c) Investigating the formation and diagnostic value of $\omega$-(o-alkylphenyl)alkanoic acids in ancient pottery. Archaeometry 63:594-608. https://doi.org/10. $1111 /$ arcm. 12631

Borić D, Grupe G, Peters J, Mikić Ž (2004) Is the Mesolithic-Neolithic Subsistence Dichotomy Real? New Stable Isotope Evidence from the Danube Gorges. Eur J Archaeol 7:221-248. https://doi.org/ 10.1177/1461957104056500

Brown TA, Nelson DE, Vogel JS, Southon JR (1988) Improved collagen extraction by modified Longin method. Radiocarbon 30:171-177

Buckley M, Collins MJ (2011) Collagen survival and its use for species identification in holocene-lower pleistocene bone fragments from British Archaeological and Paleontological sites. Antiqua 1:1-17. https://doi.org/10.4081/antiqua.2011.e1

Buckley M, Collins M, Thomas-Oates J, Wilson JC (2009) Species identification by analysis of bone collagen using matrix-assisted laser desorption/ionisation time-of-flight mass spectrometry. Rapid Commun Mass Spectrom 23:3843-3854. https://doi.org/ $10.1002 / \mathrm{rcm} .4316$

Buckley M, Whitcher Kansa S, Howard S et al (2010) Distinguishing between archaeological sheep and goat bones using a single collagen peptide. J Archaeol Sci 37:13-20. https://doi.org/10. 1016/j.jas.2009.08.020

Budja M (2005) The process of Neolithisation in South-eastern Europe: from ceramic female figurines and cereal grains to entoptics and human nuclear DNA polymorphic markers. Doc Praeh 32:53-72. https://doi.org/10.4312/dp.32.3

Budja M (2009) Early Neolithic pottery dispersals and demic diffusion in southeastern Europe. Doc Praeh 36:117. https://doi.org/ $10.4312 /$ dp. 36.7

Cauvin J (2000) The evidence of symbolism in the southern Levant. In: Cauvin J (ed) The birth of the Gods and the origins of agriculture. Cambridge University Press, pp 105-120

Chard CS (1974) Northeast Asia in Prehistory. University of Wisconsin Press, Michigan University

Childe GV (1951) Man makes himself, New edn

Choy K, Potter BA, McKinney HJ et al (2016) Chemical profiling of ancient hearths reveals recurrent salmon use in Ice Age Beringia. Proc Natl Acad Sci USA 113:9757-9762. https://doi.org/ 10.1073/pnas.1606219113

Christie WW (1989) Gas Chromatography and Lipids: A Practical Guide, 1st edn. Oily Press Ltd, Ayr

Colombini MP, Giachi G, Modugno F, Ribechini E (2005) Characterisation of organic residues in pottery vessels of the Roman age from Antinoe (Egypt). Microchem J 79:83-90. https://doi. org/10.1016/j.microc.2004.05.004

Colonese AC, Farrell T, Lucquin A et al (2015) Archaeological bone lipids as palaeodietary markers. Rapid Commun Mass Spectrom 29:611-618. https://doi.org/10.1002/rcm.7144

Copley MS, Berstan R, Dudd SN et al (2003) Direct chemical evidence for widespread dairying in prehistoric Britain. PNAS 100:1524-1529. https://doi.org/10.1073/pnas.0335955100

Copley MS, Berstan R, Dudd SN et al (2005) Processing of milk products in pottery vessels through British prehistory. Antiquity 79:895-908. https://doi.org/10.1017/S0003598X00115029

Costa MS, Rego A, Ramos V et al (2016) The conifer biomarkers dehydroabietic and abietic acids are widespread in Cyanobacteria. Sci Rep 6:e23436. https://doi.org/10.1038/srep23436

Courel B, Robson HK, Lucquin A et al (2020) Organic residue analysis shows sub-regional patterns in the use of pottery by Northern European hunter-gatherers. R Soc Open Sci 7:e192016. https://doi.org/10.1098/rsos.192016

Craig OE, Allen RB, Thompson A et al (2012) Distinguishing wild ruminant lipids by gas chromatography/combustion/isotope ratio mass spectrometry. Rapid Commun Mass Spectrom 26:2359-2364. https://doi.org/10.1002/rcm.6349

Craig OE, Forster M, Andersen SH et al (2007) Molecular and isotopic demonstration of the processing of aquatic products in Northern European Prehistoric pottery. Archaeometry 49:135152. https://doi.org/10.1111/j.1475-4754.2007.00292.x

Craig OE, Saul H, Lucquin A et al (2013) Earliest evidence for the use of pottery. Nature 496:351-354. https://doi.org/10.1038/ nature 12109

Craig OE, Steele VJ, Fischer A et al (2011) Ancient lipids reveal continuity in culinary practices across the transition to agriculture in Northern Europe. Proc Natl Acad Sci 108:17910 17915. https://doi.org/10.1073/pnas.1107202108

Cramp LJE, Ethier J, Urem-Kotsou D, et al (2019) Regional diversity in subsistence among early farmers in Southeast Europe revealed by archaeological organic residues. Proc R Soc 286:e20182347

Cramp LJE, Evershed RP (2014) Reconstructing Aquatic Resource Exploitation in Human Prehistory Using Lipid Biomarkers and Stable Isotopes. In: Holland HD, Turekian KK (eds) Treatise on Geochemistry: Archaeology and Anthropology, 2nd edn. Elsevier, Oxford, pp 319-339 
Cramp LJE, Jones J, Sheridan A et al (2014) Immediate replacement of fishing with dairying by the earliest farmers of the Northeast Atlantic archipelagos. Proc R Soc B 281:e20132372. https:// doi.org/10.1098/rspb.2013.2372

Davison K, Dolukhanov PM, Sarson GR et al (2009) Multiple sources of the European Neolithic: Mathematical modelling constrained by radiocarbon dates. Quat Int 203:10-18. https:// doi.org/10.1016/j.quaint.2008.04.013

Debono Spiteri C, Gillis RE, Roffet-Salque M et al (2016) Regional asynchronicity in dairy production and processing in early farming communities of the northern Mediterranean. Proc Natl Acad Sci 113:13594-13599

Dixon RB (1928) The building of cultures. Charles Scribner's Sons, New York; London

Dolbunova E (2016) Les premières traditions céramiques du bassin du Dnepr-Dvina au VIIe-VIe millénaires av. J.-C. (dans le contexte de la Néolithisation de l'Europe de 1'Est). Phd, Université Paris 1

Dolbunova E, Szmańda J, Kittel P, et al (2020a) Rakushechny Yar site: lacustrine and fluvial deposits, buried soils and shell platforms from 6th mill BC. Acta Geographica Lodziensis 110:61-80. https://doi.org/10.26485/AGL/2020/110/5

Dolbunova E, Tsybryi VV, Mazurkevich AN et al (2020b) Subsistence strategies and the origin of Neolithic community in the lower Don River valley (Rakushechny Yar site, early/middle 6th millennium cal BC). Quat Int 541:115-129. https://doi.org/10. 1016/j.quaint.2019.05.012

Dolukhanov PM, Mazurkevich AM, Shukurov A (2009a) Early pottery makers in Eastern Europe: centres of origins, subsistence and dispersal. In: Jordan P, Zvelebil M (eds) Ceramics before farming: the dispersal of pottery among prehistoric Eurasian hunter-gatherers. Left Coast Press, Walnut Creek, United States, pp 237-253

Dolukhanov PM, Shukurov A, Davison K et al (2009b) The Spread of the Neolithic in the South East European Plain: Radiocarbon Chronology, Subsistence, and Environment. Radiocarbon 51:783-793. https://doi.org/10.1017/S0033822200056095

Doucett RR, Hooper W, Power G (1999) Identification of anadromous and nonanadromous adult brook trout and their progeny in the Tabusintac river, New Brunswick, by means of multiple-stableisotope analysis. Trans Am Fish Soc 128:278-288. https://doi. org/10.1577/1548-8659(1999)128<0278:IOAANA > 2.0.CO;2

Dudd SN (1999) Molecular and isotopic characterisation of animal fats in archaeological pottery. University of Bristol, Phd

Dudd SN, Regert M, Evershed RP (1998) Assessing microbial lipid contributions during laboratory degradations of fats and oils and pure triacylglycerols absorbed in ceramic potsherds. Org Geochem 29:1345-1354. https://doi.org/10.1016/S0146-6380(98) 00093-X

Dufour E, Bocherens H, Mariotti A (1999) Palaeodietary Implications of Isotopic Variability in Eurasian Lacustrine Fish. J Archaeol Sci 26:617-627. https://doi.org/10.1006/jasc.1998.0379

Esmaeili HR, Hojat AT, Teymouri A (2007) Scale structure of a cyprinid fish, Capoeta damascina (Valenciennes in Cuvier and Valenciennes, 1842) using scanning electron microscope (SEM). Iranian Journal of Science \& Technology, Transaction A, 31:255-262. https://doi.org/10.22099/ijsts.2007.2342

Evershed RP (2008) Experimental approaches to the interpretation of absorbed organic residues in archaeological ceramics. World Archaeol 40:26-47. https://doi.org/10.1080/00438240801889373

Evershed RP, Copley MS, Dickson L, Hansel FA (2008a) Experimental evidence for processing of marine animal products and other commodities containing polyunsaturated fatty acids in pottery vessels. Archaeometry 50:101-113. https://doi.org/10.1111/j. 1475-4754.2007.00368.x

Evershed RP, Payne S, Sherratt AG et al (2008b) Earliest date for milk use in the Near East and southeastern Europe linked to cattle herding. Nature 455:528-531. https://doi.org/10.1038/natur $\mathrm{e} 07180$

Fernandes R, Grootes P, Nadeau M-J, Nehlich O (2015) Quantitative diet reconstruction of a Neolithic population using a Bayesian mixing model (FRUITS): The case study of Ostorf (Germany). Am J Phys Anthropol 158:325-340. https://doi.org/10.1002/ajpa. 22788

Fischer A, Heinemeier J (2003) Freshwater Reservoir Effect in 14C Dates of Food Residue on Pottery. Radiocarbon 45:449-466. https://doi.org/10.1017/S003382220003280X

Frantz LAF, Haile J, Lin AT et al (2019) Ancient pigs reveal a nearcomplete genomic turnover following their introduction to Europe. Proc Natl Acad Sci U S A 116:17231-17238. https:// doi.org/10.1073/pnas.1901169116

Fuller DQ, Kingwell-Banham E, Lucas L et al (2015) Comparing Pathways to Agriculture Archaeol Int 18:61-66. https://doi. org/10.5334/ai. 1808

Gibbs K, Isaksson S, Craig OE, et al (2017) Exploring the emergence of an "Aquatic" Neolithic in the Russian Far East: organic residue analysis of early hunter-gatherer pottery from Sakhalin Island. Antiquity 91:1484-1500. https://doi.org/10.15184/aqy. 2017.183

Gibbs K, Jordan P (2016) A comparative perspective on the "western" and "eastern" Neolithics of Eurasia: Ceramics; agriculture and sedentism. Quat Int 419:27-35. https://doi.org/10.1016/j. quaint.2016.01.069

Gonzalez Carretero L, Wollstonecraft M, Fuller DQ (2017) A methodological approach to the study of archaeological cereal meals: a case study at Çatalhöyük East (Turkey). Veget Hist Archaeobot 26:415-432. https://doi.org/10.1007/ s00334-017-0602-6

Gonzalez Carretero L (2020) On the origins of bread cultures in the Near East: a new archaeobotanical study of charred meals and cooking practices from Neolithic Çatalhöyük (Turkey) and Jarmo (Iraqi Kurdistan). University College London, $\mathrm{PhD}$

Gorelik A., Cybrij A., Cybrij V. 2016 Kaukasisch-Vorderasiatische Elemente im Frühneolithikum des Unteren Dons. Anatolien Metall VII: 1-17 [In Russian]

Gregg MW (2009) Organic Residue Analysis and the Earliest Uses of Pottery in the Ancient Middle East. University of Toronto, PhD

Gronenborn D (2008) Early pottery in Afroeurasia - origins and possible routes of dispersal. In: Hartz S, Lüth F, Terberge T (eds) Ber Romisch-Germanischen Komm, Frankfurt, pp 59-87

Hansel FA, Copley MS, Madureira LAS, Evershed RP (2004) Thermally produced $\omega$-(o-alkylphenyl)alkanoic acids provide evidence for the processing of marine products in archaeological pottery vessels. Tetrahedron Lett 45:2999-3002. https://doi.org/ 10.1016/j.tetlet.2004.01.111

Hansel FA, Evershed RP (2009) Formation of dihydroxy acids from Z-monounsaturated alkenoic acids and their use as biomarkers for the processing of marine commodities in archaeological pottery vessels. Tetrahedron Lett 50:5562-5564. https://doi.org/10. 1016/j.tetlet.2009.06.114

Hansel FA, Hayden B (2009) Foreword. In: Jordan P, Zvelebil M (eds) Ceramics before Farming: The Dispersal of Pottery among Prehistoric Eurasian Hunter-Gatherers, Publications of the Institute of Archaeology. University College London, Left Coast Press, Walnut Creek, United States, pp 19-26

Hellevang H, Aagaard P (2015) Constraints on natural global atmospheric $\mathrm{CO}_{2}$ fluxes from 1860 to 2010 using a simplified explicit forward model. Sci Rep 5:e17352. https://doi.org/10.1038/srep1 7352

Heron C, Andersen S, Fischer A et al (2013) Illuminating the Late Mesolithic: residue analysis of "blubber" lamps from Northern Europe. Antiquity 87:178-188. https://doi.org/10.1017/S0003 598X00048705 
Heron C, Craig OE, Luquin A et al (2015) Cooking fish and drinking milk? Patterns in pottery use in the southeastern Baltic, 33002400 cal BC. J Archaeol Sci 63:33-43. https://doi.org/10.1016/j. jas.2015.08.002

Hilton EJ, Grande L, Bemis WE (2011) Skeleton anatomy of the shortnose sturgeon, Acipenser brevirostrum Lesueur, 1818, and the systematics of sturgeons (Acipenseriformes, Acipenseridae). Fieldiana Life Earth Sci 3:1-168

Hommel P (2014) Ceramic Technology. In: Cummings V, Jordan P, Zvelebil M (eds) The Oxford Handbook of the Archaeology and Anthropology of Hunter-Gatherers. Oxford University Press, pp 663-693

Ikawa-Smith F (1976) On Ceramic Technology in East Asia. Curr Anthropol 17:513-515

Jackinsky-Sethi N (2014) Fish Skin as a Textile Material in Alaska Native Cultures. First American Art Magazine 5:40-47 ([In Russian])

Jordan P, Gibbs K, Hommel P, et al (2016) Modelling the diffusion of pottery technologies across Afro-Eurasia: emerging insights and future research. Antiquity 90:590-603. https://doi.org/10. 15184/aqy.2016.68

Jordan P, Zvelebil M (2009) Ex Oriente Lux: The Prehistory of HunterGatherer Ceramic Dispersals. In: Jordan P, Zvelebil M (eds) Ceramics before farming: the dispersal of pottery among prehistoric Eurasian hunter-gatherers. Left Coast Press, Walnut Creek, United States, pp 33-89

Jørkov MLS, Heinemeier J, Lynnerup N (2007) Evaluating bone collagen extraction methods for stable isotope analysis in dietary studies. J Archaeol Sci 34:1824-1829. https://doi.org/10.1016/j. jas.2006.12.020

Jovanović J, de Becdelièvre C, Stefanović S et al (2019) Last huntersfirst farmers: new insight into subsistence strategies in the Central Balkans through multi-isotopic analysis. Archaeol Anthropol Sci 11:3279-3298. https://doi.org/10.1007/s12520-018-0744-1

Kirby DP, Buckley M, Promise E et al (2013) Identification of collagen-based materials in cultural heritage. Analyst 138:4849-4858. https://doi.org/10.1039/c3an00925d

Kovalchuk O, Gorobets L, Veiber A et al (2018) Animal remains from Neolithic settlements of the Middle Dnieper area (Ukraine). Int J Osteoarchaeol 28:1-9. https://doi.org/10.1002/oa.2647[InRus sian]

Krauß R, Marinova E, De Brue H, Weninger B (2018) The rapid spread of early farming from the Aegean into the Balkans via the SubMediterranean-Aegean Vegetation Zone. Quat Int 496:24-41. https://doi.org/10.1016/j.quaint.2017.01.019

Kriiska A, Oras E, Lõugas L et al (2017) Late Mesolithic Narva Stage in Estonia: Pottery, Settlement Types and Chronology. Estonian Journal of Archaeology 21:52-86. https://doi.org/10.3176/arch. 2017.1.03

Kuhnlein HV, Chan AC, Thompson JN, Nakai S (1982) Ooligan grease: A nutritious fat used by native people of coastal British Columbia. J Ethnobiol 2:154-161

Kulkova M, Mazurkevich A, Dolbunova E (2018) Paste recipes and raw material sources for pottery-making in hunter-gatherer communities in the forest zone of Eastern Europe (Dnepr-Dvina region, 7-6th millennia BC). J Archaeol Sci Rep 21:962-972

Kuzmin YV (2013) Two Trajectories in the Neolithization of Eurasia: Pottery Versus Agriculture (Spatiotemporal Patterns). Radiocarbon 55:1304-1313

Le Mière M, Picon M (1998) Les débuts de la céramique au ProcheOrient. Paléorient 24:5-26. https://doi.org/10.3406/paleo.1998. 4674

Longin R (1971) New method of collagen extraction for radiocarbon dating. Nature 230:241-242. https://doi.org/10.1038/230241a0
Lucquin A, Colonese AC, Farrell TFG, Craig OE (2016a) Utilising phytanic acid diastereomers for the characterisation of archaeological lipid residues in pottery samples. Tetrahedron Lett 57:703-707. https://doi.org/10.1016/j.tetlet.2016.01.011

Lucquin A, Gibbs K, Uchiyama J et al (2016b) Ancient lipids document continuity in the use of early hunter-gatherer pottery through 9,000 years of Japanese prehistory. PNAS 113:3991-3996. https://doi.org/10.1073/pnas.1522908113

Lucquin A, March RJ, Cassen S (2007) Analysis of adhering organic residues of two "coupes-à-socles" from the Neolithic funerary site "La Hougue Bie" in Jersey: evidences of birch bark tar utilisation. J Archaeol Sci 34:704-710. https://doi.org/10.1016/j. jas.2006.07.006

Mazurkevich A, Dolbunova E (2015) The oldest pottery in huntergatherer communities and models of Neolithisation of Eastern Europe. Documenta Praehistorica 42:13-66

Mazurkevich A, Dolbunova E (2012) The most ancient pottery and Neolithisation of Eastern Europe. Fontes Archaeologici Posnanienses 48:143-159

Mazurkevich A, Dolbunova E, Zaitseva G, et al (2017) Chronological timeframes of cultural changes in the Dnepr-Dvina region ( 7 th to 3rd millennium BC). Doc Praehist XLIV: 162-175.

McCarthy ID, Waldron S (2000) Identifying migratory Salmo trutta using carbon and nitrogen stable isotope ratios. Rapid Commun Mass Spectrom 14:1325-1331

Milner N (2009) Mesolithic consumption practices: food for thought. Journal of Nordic Archaeological Science 16:49-64

Miller MJ, Whelton HL, Swift JA et al (2020) Interpreting ancient food practices: stable isotope and molecular analyses of visible and absorbed residues from a year-long cooking experiment. Sci Rep 10:e13704. https://doi.org/10.1038/s41598-020-70109-8

Miracle P (2002) Mesolithic meals from Mesolithic middens. In: Miracle P, Milner N (eds) Consuming passions and patterns of consumption. McDonald Institute, Cambridge, pp 65-88

Mitkidou S, Dimitrakoudi E, Urem-Kotsou D et al (2008) Organic residue analysis of Neolithic pottery from North Greece. Microchim Acta 160:493-498. https://doi.org/10.1007/s00604-007-0811-2

Modugno F, Ribechini E (2009) GC/MS in the characterisation of resinous materials. In: Colombini MP, Modugno F (eds) Organic Mass Spectrometry in Art and Archaeology. John Wiley \& Sons, pp 215-259

Motuzaite-Matuzeviciute G (2012) The earliest appearance of domesticated plant species and their origins on the western fringes of the Eurasian Steppe. Documenta Praehistorica 39:1-21. https:// doi.org/10.4312/dp.39.1

Naihuang J, Zhenyan T, Dongling R et al (1995) The discovery of retene in Precambrian and Lower Paleozoic marine formations. Chin J Geochem 14:41-51. https://doi.org/10.1007/BF02840382

Nieuwenhuyse OP, Roffet-Salque M, Evershed RP et al (2015) Tracing pottery use and the emergence of secondary product exploitation through lipid residue analysis at Late Neolithic Tell Sabi Abyad (Syria). J Archaeol Sci 64:54-66. https://doi.org/10.1016/j.jas. 2015.10.002

Nishiaki YA, Le Mière M (2005) The oldest pottery Neolithic of Upper Mesopotamia : New evidence from Tell Seker al-Aheimar, the Khabur, northeast Syria. Paléorient 31:55-68. https://doi.org/10. 3406/paleo.2005.5125

Oras E, Lucquin A, Lõugas L et al (2017) The adoption of pottery by north-east European hunter-gatherers: Evidence from lipid residue analysis. J Archaeol Sci 78:112-119. https://doi.org/10. 1016/j.jas.2016.11.010

Outram AK, Stear NA, Bendrey R et al (2009) The earliest horse harnessing and milking. Science 323:1332-1335. https://doi.org/10. 1126/science.1168594 
Ovissipour M, Rasco B (2011) Fatty acid and Amino acid Profiles of Domestic and Wild Beluga (Huso huso) Roe and Impact on Fertilization Ratio. J Aquac Res Development 2:1-6. https://doi. org/10.4172/2155-9546.1000113

Pääkkönen M, Bläuer A, Evershed RP, Asplund H (2016) Reconstructing food procurement and processing in Early Comb Ware Period through organic residues in Early Comb and Jäkärlä Ware Pottery. Fennoscandia Archaeologica XXXIII:57-75

Pääkkönen M, Evershed R, Asplund H (2020) Compound-specific stable carbon isotope values of fatty acids in modern aquatic and terrestrial animals from the Baltic Sea and Finland as an aid to interpretations of the origins of organic residues preserved in archaeological pottery. Journal of Nordic Archaeological Science (JONAS) 19:3-19

Philippsen B (2013) The freshwater reservoir effect in radiocarbon dating. Heritage Science 1:24. https://doi.org/10.1186/ 2050-7445-1-24

Piezonka H (2011) The earliest pottery east of the Baltic Sea. In: Lüth F, Terberger T (eds) Hartz S. Early Pottery in the Baltic - Dating, Origin and Social Context, pp 301-346

Raemaekers DCM, Kubiak-Martens L, Oudemans TFM (2013) New food in old pots - charred organic residues in Early Neolithic ceramic vessels from Swifterbant, the Netherlands (4300-4000 cal BC). Archäologisches Korrespondenzblatt 43:315-334. https://doi.org/10.11588/ak.2013.3.39180

Rageot M (2015) Les substances naturelles en Méditerranée nordoccidentale (VIe-Ier millénaire BCE): chimie et archéologie des matériaux exploités leurs propriétés adhésives et hydrophobes. Université Nice Sophia-Antipolis, $\mathrm{PhD}$

Raven AM, van Bergen PF, Stott AW et al (1997) Formation of longchain ketones in archaeological pottery vessels by pyrolysis of acyl lipids. J Anal Appl Pyrolysis 40-41:267-285

Regert M, Bland HA, Dudd SN et al (1998) Free and bound fatty acid oxidation products in archaeological ceramic vessels. Proc Royal Soc B 265:2027-2032. https://doi.org/10.1098/rspb.1998.0536

Regert M (2004) Investigating the history of prehistoric glues by gas chromatography-mass spectrometry. J Sep Sci 27:244-254. https://doi.org/10.1002/jssc.200301608

Richards MP, Hedges REM, Molleson TI, Vogel JC (1998) Stable Isotope Analysis Reveals Variations in Human Diet at the Poundbury Camp Cemetery Site. J Archaeol Sci 25:1247-1252. https:// doi.org/10.1006/jasc.1998.0307

Rowley-Conwy P, Foulds FWF, Drinkall HC, et al (2014) Foragers and farmers in Mesolithic/Neolithic Europe, 5500-3900 cal BC: beyond the anthropological comfort zone. Wild Things: Recent Advances in Palaeolithic and Mesolithic Research Oxford: Oxbow Books 185-201

Sablin MV (2018) Arkheozoologicheskij analiz osteologicheskogo materiala poseleniya Rakushechnyj YAr v kontekste izucheniya khozyajstva ranneneoliticheskogo naseleniya. Samarskij nauchnyj vestnik Tom 7 3:160-165 [In Russian]

Shimoyama A, Hayakawa K, Harada K (1993) Conversion of oleic acid to monocarboxylic acids and y-lactones by laboratory heating experiments in relation to organic diagenesis. Geochem $\mathbf{J}$ 27:59-70

Shoda S, Lucquin A, Ahn J-H et al (2017) Pottery use by early Holocene hunter-gatherers of the Korean peninsula closely linked with the exploitation of marine resources. Quat Sci Rev 170:164-173. https://doi.org/10.1016/j.quascirev.2017.06.032

Spangenberg JE, Jacomet S, Schibler J (2006) Chemical analyses of organic residues in archaeological pottery from Arbon Bleiche 3, Switzerland - evidence for dairying in the late Neolithic. J Archaeol Sci 33:1-13. https://doi.org/10.1016/j.jas.2005.05.013

Strohalm M, Hassman M, Kosata B, Kodícek M (2008) mMass data miner: an open source alternative for mass spectrometric data analysis. Rapid Commun Mass Spectrom 22:905-908. https:// doi.org/10.1002/rcm.3444

Taché K, Craig OE (2015) Cooperative harvesting of aquatic resources and the beginning of pottery production in north-eastern North America. Antiquity 89:177-190. https://doi.org/10.15184/aqy. 2014.36

Thieren E, Wouters W, Van Neer W (2015) Guide for the identification of archaeological sea sturgeon (Acipenser sturio and A. oxyrinchus) remains. Cybium 39:175-192

Tsybrij A, Tsybrij V, Dolbunova E et al (2017) Radiocarbon chronology of Neolithic in the Lower Don and North-eastern Azov Sea. Doc Praeh 44:204-223. https://doi.org/10.4312/dp.44.13

Vandiver P (1987) Sequential Slab Construction; A Conservative Southwest Asiatic Ceramic Tradition, ca. 7000-3000 B.C. Paléorient 13:9-35. https://doi.org/10.3406/paleo.1987.4426

Verdugo MP, Mullin VE, Scheu A et al (2019) Ancient cattle genomics, origins, and rapid turnover in the Fertile Crescent. Science 365:173-176. https://doi.org/10.1126/science.aav1002

Zabilska-Kunek M (2019) Freshwater fishing at the Neolithic site of Rakushechny Yar. Int J Osteoarchaeol 29:387-394. https://doi. org/10.1002/oa.2770

Zhukov BS (1929) Teoriya hronologicheskih i territorial'nyh modifikacij nekotoryh neoliticheskih kul'tur Vostochnoj Evropy po dannym izucheniya keramiki. Etnografiya 1:54-77 ([In Russian])

Zydlewski J, Wilkie MP (2012) Freshwater to seawater transitions in migratory fishes. In: McCormick SD, Farrell AP, Brauner CJ (eds) Fish Physiology. Academic Press, pp 253-326

Publisher's note Springer Nature remains neutral with regard to jurisdictional claims in published maps and institutional affiliations. 